
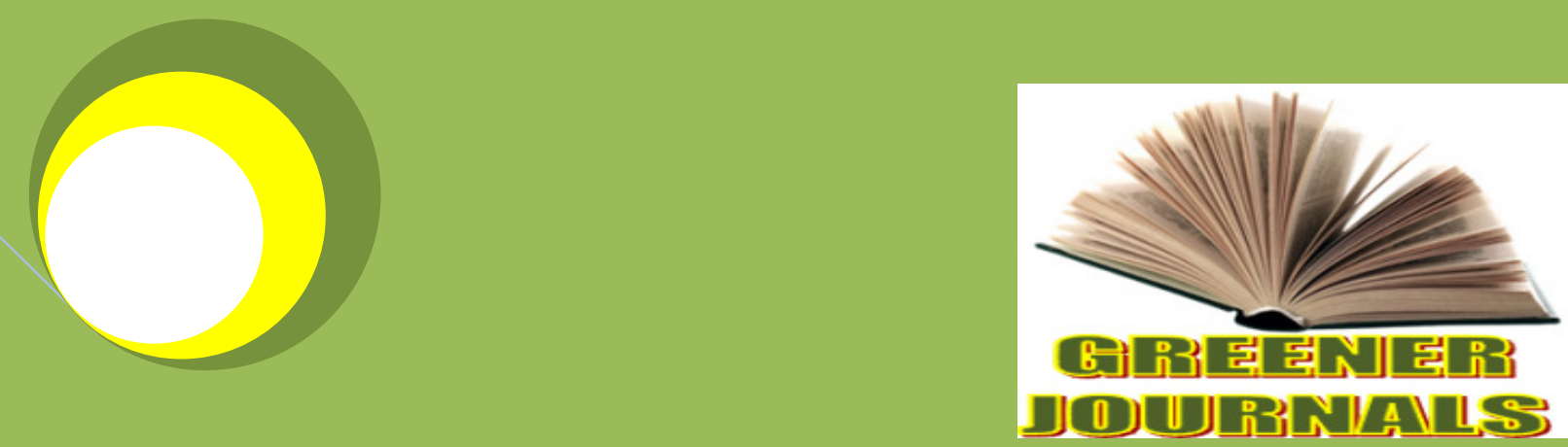

Greenert Jourrnal of Biólogical Sciences

\title{
Notes on the Floral Biology and \\ Fruiting of Cycad Circinalis in Nigeria
}

By

Odewale, J. O. Agho Collins Eziashi, E. I 


\title{
Notes on the Floral Biology and Fruiting of Cycad Circinalis in Nigeria
}

\author{
Odewale, J. O, Agho Collins and Eziashi, E. I
}

\author{
Plant Breeding Division, NIFOR, P.M.B. 1030 300001, Benin City \\ E-mail: olusesanodewale@yahoo.com
}

\begin{abstract}
The Cycas circinalis was first officially introduced into Nigeria by the Nigerian Institute for Oil Palm Research (NIFOR), Benin City. It belongs to the Division: Cycadophyta, Class: Cycadopsida, Order Cycadales, family Cycadaceae and genera Cycas. It was first recognized as a separate species in 1995. It is also known as Sago palm, Fern palm, Cycad or Starch palm. The floral biology of the plant is cone like as other cones in the Order Cycadales, the cone has the whorl of premature pinnate fronds embedded within the cone. This cone opens up and spreads out as the inflorescence reaches anthesis revealing the whorl of young leaves that will form the new generation crown. The mean number of fully formed fruits per stalk is 9.0 average fruit length is $5.24 \mathrm{~cm}$, fruit circumference ranged from 8.6-9.6cm while the average circumference is 9.03 . Fruit weight range between $19.2-22.10 \mathrm{~g}(\mathrm{mean}=21.6 \mathrm{~g})$, the length of dehusked fruit vary from $4.1-5.0 \mathrm{~cm}$, while the circumference of the dehusked fruit range between $7.1-$ $8.0 \mathrm{~cm}$. The average circumference of dehusked fruit was $7.53 \mathrm{~cm}$. The weight of the dehusked fruit range between 9.7 $-18.6 \mathrm{~g}$, with a mean weight of $13.9 \mathrm{~g}$.
\end{abstract}

Key words: Cycas, Gymnospermous, Cone and Cycasin

\section{INTRODUCTION}

The genera Cycas belongs to the Division: Cycadophyta, Class: Cycadopsida, Order: Cycadales, Family Cycadaceae. The common name of the genera is fern palm or Sago Palm (Hall and Jenik 1967; Gregory 2001, Walter et al. 2004). It is a palm like evergreen, gymnospermous, dioecious plant having large pinnate compound leaves. They are distributed within the tropical and subtropical areas of the world. It is a source of green vegetable, laundry starch and tasty to chew. The fresh sap is thought to promote healing of open wounds, while its young leaves are grazed by live stock during drought. It produces Cycasin which has herbicidal properties, inhibiting seed germination and seedling growth of the members of the family Gramineae, Crucifereae and Leguminosae. It also fixes atmospheric nitrogen in association with Cyanobacteria living in its roots. Cycad is an endangered species, hence there is need for its germplasm conservation (Gregory, 2001, Jones 2002). There are nine known living genera in this family, and they are distributed in the tropical and subtropical areas of the world. In the natural habitat, the Cycas is a threatened species, therefore plans for its genetic conservation is urgent (Hill et al.; 2004).

The species is native to Guam since it was recognized as a separate species of Cycas (Hill 1995). In areas where Cycad is indigenous, it provides source of green vegetables, while the starchy parts (seed, rhizome and stem) provides laundry starch. The sprouts and leaves are used as green vegetables and the dried husk as tasty chew. The fresh sap promotes healing of open wounds, while the fresh young leaves are grazed by livestock during drought or bush burning. The starch is also edible when the poisonous toxin had been removed through a process described by Stevenson and Osborne 2004.

Cycads produce cycasin which is a toxic glycoside that inhibits seed germination and seedling growth of the families of Gramineae, Crucifereae and Leguminosae. Rice plants are most sensitive but soybean is tolerant. Cycasin can be used as herbicide. Various Cycads species are used as food, for rituals, medicine and cultural ceremonies. The various genera of the Cycadaceae family are found in Africa, Australia, Asia, Mexico/Honduras, Cuba, Columbia, North, Central and South America and the Caribbean (Golding and Hurter, 2003).

Cycads were first officially introduced into Nigeria as an ornamental palm by the Nigerian Institute for Oil Palm Research (NIFOR), Benin City formerly the West African Institute for Oil Palm Research (WAIFOR) in 1975, and for a long time maintained that status. Two species were introduced officially into Nigeria; these were Cycas revoluta and Cycas circinalis. Both species have feather like leaves arranged in a rosette that crown the single trunk, but the circinalis is larger and more graceful than Cycas revoluta (Chamberlain 1990).

Both of them have become very important in the horticultural landscape of Nigeria, especially around homes and institutions, horticultural gardens and offices (Nwaobasi, L. N. 2008). It is now necessary to identify 
the economic importance of the plant outside its ornamental value in Nigeria. Its seeds attract high market value e.g. in 2003, five seeds of Cycas circinalis attracted 2.25 USD in 2003 in the international market (Donaldson et al, 2003). The seed usually germinate $8-12$ weeks after sowing (Tang 2003).

The major usefulness of the fruit is for starch production; therefore efforts to improve its fruit component will be useful. It has also been reported to fix nitrogen in association with a Cyanobacteria living in its roots. These blue-green algae produce a neurotoxin that is usually found in the fruits of the cycads.

\section{MATERIALS AND METHODS}

The data presented was collected from Cycas Circinalis species planted in the Nursery area of the Nigerian Institute for Oil Palm Research (NIFOR), Benin City, Nigeria, between July and August which coincided with the time of the year when the fruits were maturing.

Twenty (20) fruits were collected from each palm. The fruits were dried at room temperature until the temperature became constant. The inflorescence of the Cycads were harvested and information was collected on the following characters: the number of fruits per stalk, length of nuts, length of dehusked nuts, circumference of dehusked nuts, weight of nuts, and weight of dehusked nuts. Other botanical observations were made on the plant and its fruits.

\section{RESULT}

Table 1: CHARACTERISTICS OF Cycas circinalis SEEDS IN NIGERIA

\begin{tabular}{|l|l|l|l|l|l|l|l|}
\hline S/N & NOF/ST & LOF & COF & WOF & LODF & CODF & WODF $(g)$ \\
\hline Range & $6-13$ & $5.0-5.5$ & $8.6-9.6$ & $19.2-22.10$ & $4.1-5.0$ & $7.1-8.0$ & $9.7-18.6$ \\
\hline Mean & $8.99 \pm 1.25$ & $5.24 \pm 0.045$ & $9.03 \pm 0.06$ & $21.6 \pm 0.343$ & $4.5 \pm 0.08$ & $7.53 \pm 0.10$ & $13.9 \pm 1.19$ \\
\hline
\end{tabular}

Key:

$\mathrm{NOF} / \mathrm{ST}=$ Number of Fruits per Stalk $\quad$ LOF $=$ Length of Fruit $(\mathrm{cm})$

$\mathrm{COF}=$ Circumference of Fruit $(\mathrm{cm}) \quad$ WOF $=$ Weight of Fruit $(\mathrm{g})$

LODF $=$ Length of Dehusked Fruit $(\mathrm{cm})$ CODF $=$ Circumference of Dehusked Fruit $(\mathrm{cm})$

WODF $=$ Weight of Dehusked Fruit

From Table 1, the number of fully formed fruits per stalk range from six to thirteen, with a mean of 8.99 , the length of fruit ranges from $5.0-5.5 \mathrm{~cm}$ with an average of $5.24 \mathrm{~cm}$, the circumference of the fruit ranges from 8.6-9.6cm while the average circumference is 9.03. The weight of fruit ranges from $19.2-22.10 \mathrm{~g}$ and the average fruit weight is $21.6 \mathrm{~g}$, the length of dehusked fruit varies from $4.1-5.0 \mathrm{~cm}$, while the circumference of the dehusked fruit range from $7.1-8.0 \mathrm{~cm}$ and the average circumference of dehusked fruit was $7.53 \mathrm{~cm}$. The weight of the dehusked fruit ranges from $9.7-18.6 \mathrm{~g}$, while the average weight of the dehusked fruit was $13.9 \mathrm{~g}$ as indicated in Table 1.

Unlike, in Encephalatos barteri which has the cone formed at the centre of the rosette leaf crown, the fruit of the Cycas circinalis is located at the base of the leaf crown as shown in figure $1 \mathrm{~b}$. The unpollinated ovary remained shrivelled on the stalk even when the fruits have reached maturity stage as indicated in Table 1c. The mature dry fruit is orange in colour as shown in figure $1 \mathrm{~d}$. The testa of the dry fruit is leathery and greyish in colour as shown in figure $1 \mathrm{e}$.

In figure 1f, the cone-shaped inflorescence carries the ovary on its lamina, and the whorl of new fronds which will later give support to the developing fruits are also enclosed in the cone. The stalk of the infructuscence is the vestigial frond of the frond.

\section{Figure 1: Cycas Circinalis}

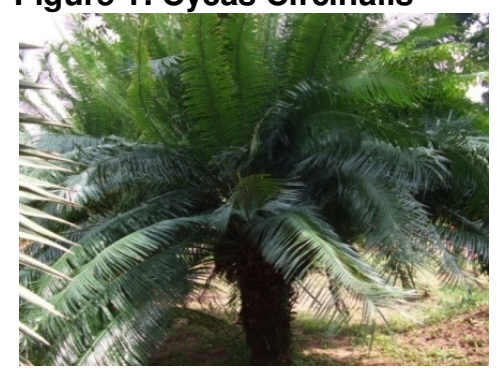

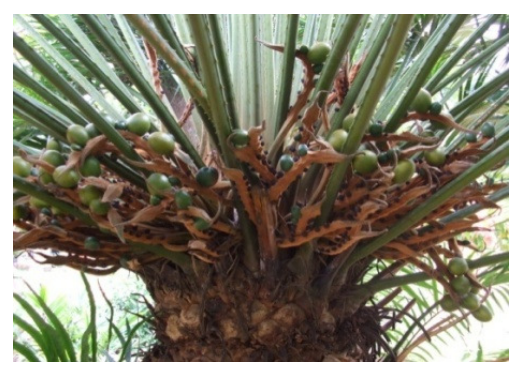


a. MATURE Cycas circinalis circinalis

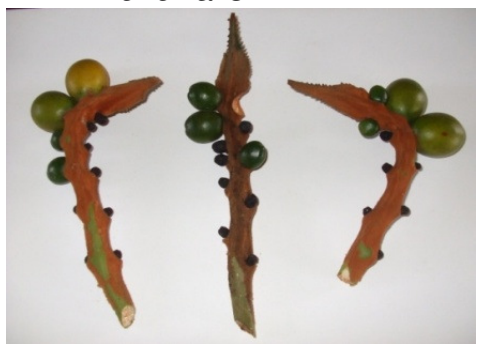

a. STALK \& FRUIT OF Cycas Circinalis

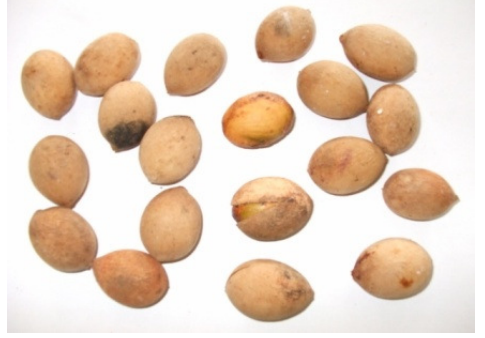

e. DEHUSKED Cycas Circinalis FRUITS
C.

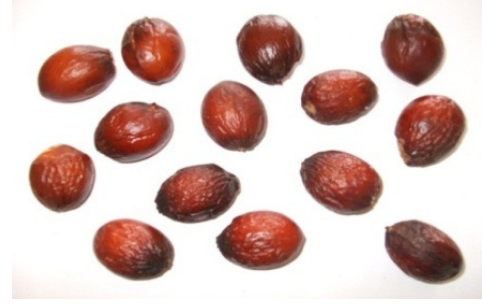

d. DRIED FRUITS OF Cycas Circinalis

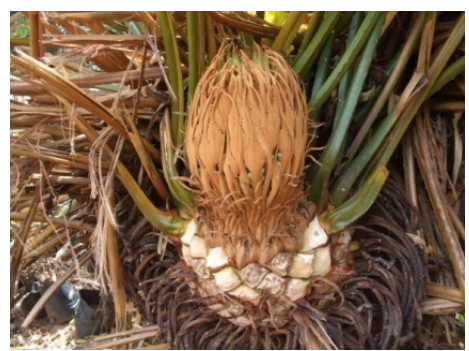

f. CONE-SHAPED INFLORESCENCE.

\section{CONCLUSION}

Cycas circinalis has adapted well as an ornamental crop in Nigeria and is currently planted universally although the potential economic use of its products is yet to be investigated. The investigation of the various economic importance of the Cycas circinalis will further encourage its planting as it adapted to the relatively arid regions of the country and as indoor decorative plant be planted in arid regions of the country as well as used as indoor and outdoor plants in offices and homes because of its slow growth rate, and to reduce erosion and serve as a check for greenhouse effect.

\section{REFERENCES}

Chamberlain, C. J. (1990). The Living Cycas. University of Chicago Press. Chicago. 40p

Gregory, T. J. (2001). Species Recognition and Classification: Concepts and Recommendation, CABI, Oxford. Pp 23-44.

Golding, J. S. and P. J. H. Hurtler (2003). A Red list Account of Africa's Cycads and Implications of considering Life History and Threats. Biodiversity and Conservation 12: $507-528$.

Hall, J. B. and J. Jenik (1967). Observation on the West African cycad in Ghana. The Nigerian Field 32: 75-81.

Hill, K. D. (1995). The Natural History of Cycas. The Plant Life: Cambridge University Press, Cambridge. 600p.

Hill, K. D., D. W. Stevenson and R. Osborne (2004) The World List of Cycas. Botanical Review. 70: 274-298.

Jones, D. L. (2002). Cycas of the world. Ancient Plants in Today's Landscape. Reed New Holland. Sydney. 288p. Lodge, D. L. (1993). Cycads of the World. Smithsonian Institution Press, Washington.

Nwaobasi, L. N. (2008). Cycas circinalis and its Horticultural Potential. Department of Plant Biology and Biotechnology, Undergraduate Seminar Series. University of Benin, Nigeria. 17p.

Stevenson, D. W. and Osborne, R. (2004). The World List of Cycas. Botanical Review. 70: 291-310.

Walters, T., Osborne, R. and Decker, D. (2004) Biology of Cycas. Cornell University Press, Ithaca. 200p. 